\title{
Influencing Factors of Azerbaijan and China's Sustainable Tourism Development Strategy under the One Belt One Road Initiative
}

\author{
Yiming Liu and Sunhee Suk * \\ Graduate School of Fisheries and Environmental Sciences, Nagasaki University, Nagasaki 852-8521, Japan; \\ bb53421008@ms.nagasaki-u.ac.jp \\ * Correspondence: suksunhee@nagasaki-u.ac.jp
}

check for updates

Citation: Liu, Y.; Suk, S. Influencing Factors of Azerbaijan and China's Sustainable Tourism Development Strategy under the One Belt One Road Initiative. Sustainability 2022, 14 187. https://doi.org/10.3390/ su14010187

Academic Editor: Nikolaos Boukas

Received: 28 October 2021

Accepted: 20 December 2021

Published: 24 December 2021

Publisher's Note: MDPI stays neutral with regard to jurisdictional claims in published maps and institutional affiliations.

Copyright: (C) 2021 by the authors. Licensee MDPI, Basel, Switzerland. This article is an open access article distributed under the terms and conditions of the Creative Commons Attribution (CC BY) license (https:// creativecommons.org/licenses/by/ $4.0 /)$.

\begin{abstract}
After the Belt and Road Initiative (BRI) was put forward, the tourism industry between Azerbaijan and China developed rapidly, and gradually became an important area of cooperation between the two countries to promote economic cooperation, non-governmental exchange, and cultural exchange. However, there is currently a lack of research on the development strategy of tourism cooperation between the two countries under the BRI. This paper aims to explore the development strategy of sustainable tourism cooperation between Azerbaijan and China under BRI through a hybrid model of SWOT (Strengths, Weaknesses, Opportunities, and Threats) and AHP (Analytic Hierarchy Process). The factor elements of the SWOT matrix introduce ambiguity due to the complex layering of elemental importance. Therefore, the AHP method was used to systematically evaluate the importance of strategic factors and reduce the subjective bias caused by the SWOT analysis method. By constructing the Delphi-AHP-SWOT strategic quadrilateral and calculating the azimuth of the strategy type, the type and intensity map of the tourism cooperation development strategy between Azerbaijan and China under the BRI is drawn. Finally, it is concluded that the development strategy of tourism cooperation between Azerbaijan and China is a pioneering development strategy. Suggestions are given for future development. This paper provides a valuable experience for the sustainable development of tourism cooperation among countries under the BRI.
\end{abstract}

Keywords: SWOT-AHP; sustainable tourism; BRI; Belt and Road

\section{Introduction}

The Belt and Road China Silk Road regional development strategy (referred to as the Belt and Road Initiative; BRI) was initially proposed in 2013. The BRI puts forward a specific plan to comprehensively solve the problem of sustainable development [1]. At present, it has had an extensive global impact and led to large leaps in cooperation between China and other countries [2,3]. As of January 2021, China has signed cooperation agreements with 171 countries and international organizations, many of which are related to tourism cooperation [4]. The BRI is a new model of international regional economic cooperation driven by China, and a national strategy for coordinating China's comprehensive opening up in various fields $[5,6]$. The BRI has been recognized by the United Nations as one of the solutions to promote the implementation of the sustainable development agenda. The BRI was intended to greatly benefit the tertiary industry, including tourism, and owing to its strong spatiality, create high-level development opportunities for regions $[7,8]$.

Azerbaijan, located at the crossroads between Europe and Asia, represents the shortest route from China to West Asia [9], and thus plays an important role in the construction of the Belt and Road [10]. Since the establishment of diplomatic relations between Azerbaijan and China in 1992, the two countries have signed about 50 agreements. In 2015, Azerbaijan became a founding member of the Asian Infrastructure Investment Bank under the BRI [11]. In 2017, the Baku-Tbilisi-Kars railway officially entered into service, offering high potential for the comprehensive advancement of the Belt and Road construction in Azerbaijan [12,13]. 
In terms of tourism cooperation, Azerbaijan and China formally signed a Memorandum of Understanding on Tourism Implementation Plan on 1 March 2019. Azerbaijan has introduced simplified electronic visas, opened regular direct flights with Beijing, and held multiple B2B tourism exhibitions aimed at the Chinese tourism market, promoting a steady rise in the number of inbound Chinese tourists [14]. Therefore, formulating a scientific tourism cooperation development strategy is particularly important for the development of sustainable tourism between the two countries under the BRI.

The main focus of the current research related to the BRI is China's motivations [15,16], the role of sustainable development $[17,18]$, and specific implementation plans $[19,20]$. Attention is also focused on infrastructure construction under the BRI [21,22], trade [23,24], environment [25,26], and education [27,28]. However, little research has covered tourism under the BRI $[29,30]$, and no research has specifically studied tourism cooperation between China and Azerbaijan under the BRI. This paper mainly uses the SWOT-AHP method for research. SWOT analysis is a widely used qualitative analysis tool for systematically analyzing internal and external environments to support decision-making [31]. The Analytic Hierarchy Process (AHP) is a multi-criteria decision analysis (MCDA) method used to assist and solve complex decision-making problems [32,33]. AHP is widely used in various fields, such as environment management [34,35], decision-making [36,37], and customer requirements [38,39]. However, since SWOT analysis does not include quantitative analysis, it is often combined with MCDA [40-42], most commonly in the form of SWOT-AHP [43]. The AHP method can measure the weight and strength of SWOT groups and factors [44], which can improve the reliability of SWOT analysis. Many researchers in different disciplines have achieved good results by using the SWOT-AHP hybrid model [45-47], and this method has also been applied to tourism strategy research $[48,49]$.

Under the above background, it is imperative to conduct research on tourism cooperation between Azerbaijan and China under the BRI. Results from such research can promote the development of interconnected tourism between Azerbaijan and China and also help in formulating clear guidelines for the sustainable development of tourism cooperation between the two countries. Therefore, the purpose of this research is (1) to use SWOT-AHP to analyze the tourism cooperation strategy between Azerbaijan and China based on the Delphi method under the BRI and provide a forward-looking strategy for the sustainable development of tourism cooperation between the two countries, and (2) provide valuable knowledge for the sustainable development of tourism cooperation in other countries under the BRI.

\section{Model Establishment}

\subsection{Delphi Method}

The Delphi method involves consulting experts via the use of questionnaires, in which after several rounds of questioning, convergence in any of the opinions expressed can lead to more accurate predictions. The Delphi method, involving soliciting opinions from experts, is considered one of the most effective methods of identifying factors that can influence decisions or strategies. The method is characterized by anonymity, feedback, convergence, and statistics, and is advantageously used in the absence of certain evaluation criteria. The method generally requires about 40 to 50 experts, but has involved up to around 700 in successful prediction cases to date [50].

\subsubsection{First Round}

Based on the existing tourism cooperation literature and guidance provided by the expert group, which comprised 20 professionals in the field of tourism (Table 1), 20 relevant indicators affecting the sustainable development of tourism cooperation between Azerbaijan and China were listed and used to construct the questionnaire. Afterwards, 700 tourists (overnight tourists) travelling from China to Azerbaijan were randomly selected for a questionnaire survey over a period from January 2018 to October 2019. 
Table 1. Backgrounds of Experts.

\begin{tabular}{|c|c|c|c|}
\hline Background & $\begin{array}{l}\text { Occupation or } \\
\text { Department }\end{array}$ & $\begin{array}{c}\text { Number of } \\
\text { People Chosen }\end{array}$ & Job \\
\hline \multirow[b]{2}{*}{$\begin{array}{l}\text { Administration } \\
\text { institution }\end{array}$} & Azerbaijan Tourism Board & 2 & $\begin{array}{l}\text { Executive in } \\
\text { related business }\end{array}$ \\
\hline & $\begin{array}{c}\text { Heilongjiang Provincial } \\
\text { Bureau of Culture } \\
\text { and Tourism }\end{array}$ & 2 & $\begin{array}{l}\text { Executive in } \\
\text { related business }\end{array}$ \\
\hline \multirow{3}{*}{ Public university } & Hunan Normal University & 3 & $\begin{array}{l}\text { Professor in related } \\
\text { research direction }\end{array}$ \\
\hline & Yunnan University & 2 & $\begin{array}{l}\text { Professor in related } \\
\text { research direction }\end{array}$ \\
\hline & Heihe University & 5 & $\begin{array}{l}\text { Professor in related } \\
\text { research direction }\end{array}$ \\
\hline \multirow{2}{*}{ The travel agency } & $\begin{array}{c}\text { Azerbaijan JT } \\
\text { World-Class travel }\end{array}$ & 3 & $\begin{array}{l}\text { Executive in } \\
\text { related business }\end{array}$ \\
\hline & China Ctrip travel & 3 & $\begin{array}{l}\text { Executive in } \\
\text { related business }\end{array}$ \\
\hline
\end{tabular}

The selection rate of the indexes was $61.8 \%$ of the 625 returned questionnaires. Among them, 14 indexes were selected 386 times, while six were selected at a rate of less than $61.8 \%$. It was therefore concluded that these six indicators were not relevant to the topic under study and were omitted from this research.

\subsubsection{Second Round}

After the first round of questionnaires, indicators with selection rates less than $61.8 \%$ were deleted. New questionnaires were then distributed to the expert group. Based on the feedback from the second round of expert groups, indicators were deleted, modified, or added. This provided the SWOT matrix for the development of tourism cooperation between Azerbaijan and China under the BRI.

\subsubsection{Third Round}

The expert team used the Likert 5-point scale to evaluate the importance and feasibility of the 20 indicators. It means that each item must be answered on a Likert 5-points scale (from $1=$ strongly disagree to $5=$ strongly agreeing) [51]. By adding up each item score, the higher the score, the stronger the expert's attitude.

\subsection{SWOT}

SWOT (Strengths, Weaknesses, Opportunities, and Threats) analysis is a method of analysis based on internal factors and external competition conditions, and is used to aid decision-making processes or analyze a certain status-quo [52]. It is also known as SWOT matrix, and has often been used in the field of business, as well as extended for use in natural resource management in order to assess a given decision, project, or policy directive in a systematic manner [53-55]. While SWOT has been used in the assessments of sustainable tourism [56], the related planning processes, however, are often quite complex due to the many standards and interdependencies involved; thus, SWOT analysis does not provide the requisite accuracy in certain contexts $[57,58]$.

Therefore, this research made use of both SWOT analysis and a questionnaire survey in order to more accurately analyze the internal factors (strengths and weaknesses) and external environment (opportunities and threats) that affect the development of tourism cooperation between Azerbaijan and China under the BRI. 


\subsubsection{Strengths}

S1: Azerbaijan and China have strengthened the strategic deployment of tourism development.

In 2015, the President of Azerbaijan and China's president Xi Jinping signed a number of cooperation documents, including the Memorandum of Understanding on the Joint Promotion of the Construction of the Silk Road Economic Belt, which provided guidance and legal assurance for tourism cooperation between the two countries. In 2016, the President of Azerbaijan signed an order to formulate a strategic road map for developing the tourism industry and providing visas on arrival for Chinese tourists.

S2: The foundations for the development of tourism in Azerbaijan and China are strong.

In recent years, Azerbaijan has made great efforts to improve the quality and efficiency of tourism development and actively launched more high-quality tourism brands. In order to attract tourists, the country introduced a system of issuing visas on arrival, launched a tax refund policy for foreign tourists in 2016 [58], and also launched the Baku International Shopping Festival. According to statistics from the Azerbaijani government, the country currently receives approximately three million tourists a year, a large increase compared to the approximately 2.06 million noted in 2016.

S3: The tourist markets of Azerbaijan and China are highly complementary.

China needs the Caucasus tourism market represented by Azerbaijan to meet the increasingly diverse tourism needs of the Chinese people. The historical and cultural characteristics of Azerbaijan, which are mainly Baku and Sheki, a mixture of the East and West, also attract Chinese tourists. The Chinese cities of Beijing, Nanjing, and Shanghai are rich in oriental culture, and have a strong appeal for Azerbaijanis.

S4: Azerbaijan and China both have rich tourism resources and high potential for cooperation.

Azerbaijan is located at the crossroads of the Eurasian continent, and the multiple legacies of Azerbaijan and China have created distinctive natural landscapes. Exchanges flow of people between the two countries can be traced back to the ancient Silk Road more than 2000 years ago, from which time the related culture, inherited by both countries, has further strengthened the bonds between them.

\subsubsection{Weaknesses}

W1: Uneven development in the field of tourism cooperation.

The cooperation between Azerbaijan and China mainly concerns trade tourism and sightseeing tourism, and the development of tourism products based on religious, historical, and gastronomic culture is insufficient.

W2: The image of tourism needs to be improved.

On the one hand, reports of Chinese tourists visiting Azerbaijan and behaving in an uncivilized or disrespectful manner have surfaced. According to the halo effect (tourism psychology) [56,57], this will cause the Azerbaijani people to resent Chinese tourists. This situation is exacerbated by prejudice and stereotypes perpetrated by the Chinese concerning Azerbaijan's military conflict and state of economy.

W3: Azerbaijan's tourism infrastructure services lag behind those of China.

The country's flight capacity is insufficient, and the price of air tickets is relatively high. Furthermore, it has insufficient hotels, the quality of which is generally low. In terms of the service quality of travel agencies, it is uneven, which affects the overall travel experience of tourists.

W4: Azerbaijan's legal system and administrative efficiency are weak.

In recent years, the country has promulgated a corresponding tourism law to guide the future development of tourism, but this has not resulted in any provisions on specific regulations or service guidelines for tourism. At the same time, the state government appears to operate inefficiently, while adhering to rent-seeking power and arbitrary law enforcement. 


\subsubsection{Opportunities}

O1: Guarantee of a comprehensive strategic partnership of coordination between Azerbaijan and China in the new era

Strengthening this partnership is one of the priorities of the foreign policies of the respective countries. Friendly bilateral relations have had a positive impact on the development of tourism cooperation between the two countries.

O2: Strong support for the BRI

Since the inception of BRI in 2013, its construction and development have together received growing interest from countries worldwide [59]. In 2015, the President of Azerbaijan and President Xi Jinping signed a Memorandum of Understanding on Jointly Promoting the Construction of the Silk Road Economic Belt and other cooperation documents. In so doing, the BRI has greatly expanded the scope of bilateral cooperation as well as greatly advanced tourism cooperation between the two countries.

O3: China attaches great importance to the cultural and tourism integration model of the tourism industry.

Azerbaijan is an important node for China and Central Asian countries towards the advancement of the BRI. The Chinese government and research institutes are increasingly focusing on integrating culture and tourism in research on the Belt and Road [60].

O4: The very high number of tourism consumers in China and Central Asia offers a guarantee of a stable source for investment income.

The investment market in Central Asia includes Central Asia, Russia, and China. These three countries represent a potential tourism consumption market of more than 1.5 billion people, which provides potential consumption support for investment.

\subsubsection{Threats}

T1: The economic development of Azerbaijan and China is unstable.

In recent years, the number of Chinese outbound tourists has increased significantly. However, since 2017, the Sino-US trade dispute has affected the development of the tourism industry [61]. Furthermore, due to the drop in international oil prices in 2014, Azerbaijan's economy was greatly impacted, and the country's population was more inclined to choose cheaper domestic travel [62].

T2: Enthusiasm for non-governmental tourism cooperation between Azerbaijan and China has not been fully mobilized.

In recent years, high-level interactions between Azerbaijan and China have been frequent, but there has been little interaction between non-governmental organizations. Further, the lack of platforms as well as gaps in communication between the two countries has resulted in some prejudice and negative impressions of citizens of Azerbaijan being circulated among the Chinese.

T3: Differences in cultural cognition between Azerbaijan and China

Differences between cultures often leads to cultural conflicts and misunderstandings. Due to differences in the natural environment, social environment, and historical development process, Azerbaijan and China have formed different national cultures, traditional values, and behavioral norms.

T4: Competition in the tourism markets of other countries and regions is fierce.

Due to the advantages of the geographic location and similar cultural customs of the countries of East Asia and Southeast Asia, these are more popular with Chinese tourists. Azerbaijani tourists are more likely to travel to CIS countries and Europe, which is closer and more similar in terms of culture. This has had a great impact on the tourism markets of Azerbaijan and China.

\subsection{AHP (Analytic Hierarchy Process)}

The AHP method is based on the MCDM principle, and is widely used to measure different strategic goals at the macroeconomic level [63]. It is very efficient at identifying, analyzing, and solving complex decision-making problems [64]. AHP also offers the 
flexibility of setting goals [65], and is practical and effective in dealing with complex decision-making problems $[66,67]$. Therefore, the AHP method has been widely used in various fields [68]. However, it suffers from some defects; for example, it is criticized for its possible rank reversal phenomenon [69].

\subsubsection{Building a Hierarchical Analysis Structure}

Based on the factors obtained by the SWOT analysis method, this article uses YAAHP software, version 12.6 to construct a hierarchical analysis structure graph (Figure 1).

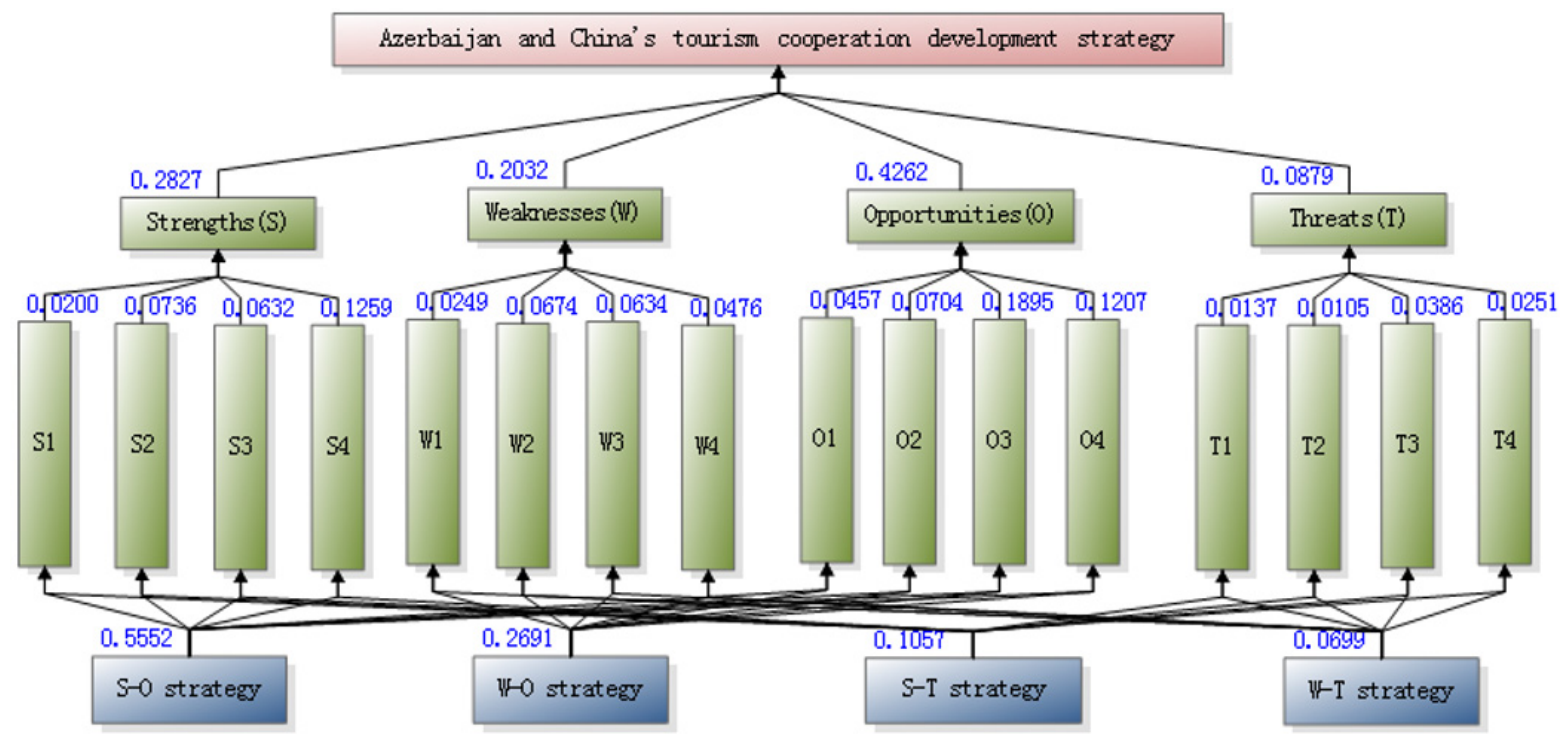

Figure 1. Hierarchical analysis structure graph.

\subsubsection{Weight and Consistency Check}

A model was built by entering data into the YAAHP 12.6 software. This reveals the weight of each element in the matrix, which can be used to determine whether the matrix is consistent. In the present case, it is confirmed that all matrices are consistent (see Table 2).

Table 2. Intensity of factors of Azerbaijan and China's tourism cooperation development strategy under BRI.

\begin{tabular}{|c|c|c|c|c|c|c|}
\hline Factors & Weights & $\begin{array}{l}\text { Factors within } \\
\text { the Group }\end{array}$ & CR & $\lambda \max$ & $\begin{array}{l}\text { In-Group } \\
\text { Weight }\end{array}$ & $\begin{array}{l}\text { Overall } \\
\text { Weight }\end{array}$ \\
\hline \multirow{4}{*}{$S$} & \multirow{4}{*}{0.2827} & S1 & \multirow{4}{*}{0.0987} & \multirow{4}{*}{4.2635} & 0.0707 & 0.02 \\
\hline & & S2 & & & 0.2603 & 0.0736 \\
\hline & & S3 & & & 0.2236 & 0.0632 \\
\hline & & $\mathrm{S} 4$ & & & 0.4453 & 0.1259 \\
\hline \multirow{4}{*}{ W } & \multirow{4}{*}{0.2032} & W1 & \multirow{4}{*}{0.0771} & \multirow{4}{*}{4.206} & 0.1225 & 0.0249 \\
\hline & & W2 & & & 0.3317 & 0.0674 \\
\hline & & W3 & & & 0.312 & 0.0634 \\
\hline & & W4 & & & 0.2343 & 0.0476 \\
\hline \multirow{4}{*}{$\mathrm{O}$} & \multirow{4}{*}{0.4262} & O1 & \multirow{4}{*}{0.0267} & \multirow{4}{*}{4.0712} & 0.1072 & 0.0457 \\
\hline & & $\mathrm{O} 2$ & & & 0.1652 & 0.0704 \\
\hline & & $\mathrm{O} 3$ & & & 0.4446 & 0.1895 \\
\hline & & $\mathrm{O} 4$ & & & 0.2832 & 0.1207 \\
\hline \multirow{4}{*}{$\mathrm{T}$} & \multirow{4}{*}{0.0879} & $\mathrm{~T} 1$ & \multirow{4}{*}{0.0543} & \multirow{4}{*}{4.145} & 0.1559 & 0.0137 \\
\hline & & $\mathrm{T} 2$ & & & 0.1195 & 0.0105 \\
\hline & & $\mathrm{T} 3$ & & & 0.4391 & 0.0386 \\
\hline & & $\mathrm{T} 4$ & & & 0.2856 & 0.0251 \\
\hline
\end{tabular}




\subsubsection{Calculation of the Intensity of Factors}

The magnitude of the factor's effect is expressed as the Intensity, and its actual level is the Estimated Strength; thus, Intensity $=$ Estimated Strength $\times$ Weight. The scoring method, which makes use of the Likert five-level scale, involved 20 experts to score each factor, wherein $\mathrm{W}$ and $\mathrm{T}$ are represented by negative values. In this representation, the greater the absolute value, the greater the intensity.

\subsubsection{Construction of AHP-SWOT Strategic Quadrilateral}

The strategic quadrilateral (Figure 2) was drawn based on the calculation results of the total intensities of each group. The results are shown in Table 3.

$$
\sum_{\mathrm{Oi}}=1.7600>\sum_{\mathrm{Si}}=1.0611>\sum_{\mathrm{W}_{\mathrm{i}}}=-0.8237>\sum_{\mathrm{Ti}}=-0.3016
$$

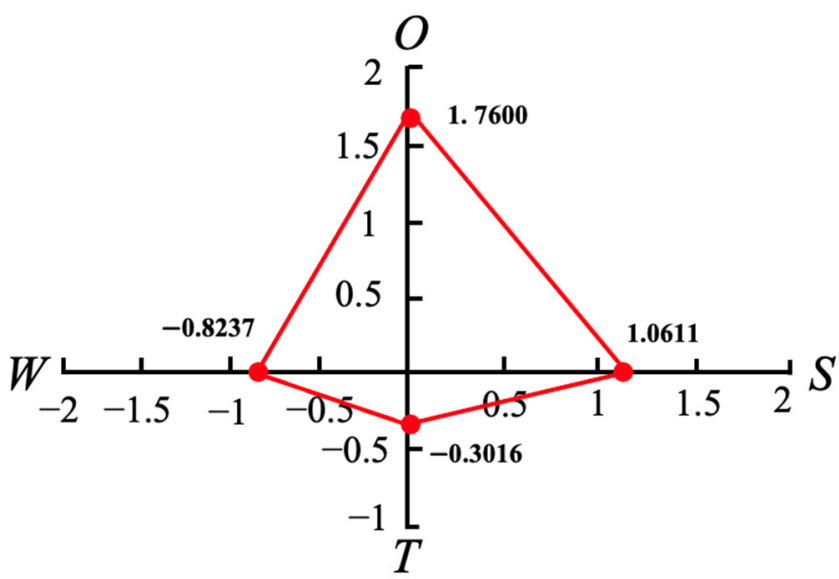

Figure 2. AHP-SWOT strategic quadrilateral.

Table 3. Intensities of groups and factors.

\begin{tabular}{ccccc}
\hline SWOT Group & Factor Weight & $\begin{array}{c}\text { Estimated } \\
\text { Strength }\end{array}$ & $\begin{array}{c}\text { Strategic } \\
\text { Strength }\end{array}$ & Total Intensity \\
\hline \multirow{5}{*}{ Strengths $(\mathrm{S})$} & $\mathrm{W}_{\mathrm{S} 1}=0.0707$ & 4.15 & 0.0830 & \\
& $\mathrm{~W}_{\mathrm{S} 2}=0.2603$ & 3.70 & 0.2723 & $\sum_{\mathrm{Si}}=1.0611$ \\
& $\mathrm{~W}_{\mathrm{S} 3}=0.2236$ & 3.40 & 0.2148 & \\
& $\mathrm{~W}_{\mathrm{S} 4}=0.4453$ & 3.90 & 0.4910 & \\
\hline \multirow{5}{*}{ Weaknesses $(\mathrm{W})$} & $\mathrm{W}_{\mathrm{W} 1}=0.1225$ & -3.35 & -0.0834 & \\
& $\mathrm{~W}_{\mathrm{W} 2}=0.3317$ & -4.15 & -0.2797 & $\sum_{\mathrm{Wi}}=-0.8237$ \\
& $\mathrm{~W}_{\mathrm{W} 3}=0.3120$ & -4.45 & -0.2821 & \\
& $\mathrm{~W}_{\mathrm{W} 4}=0.2343$ & -3.75 & -0.1785 & \\
Opportunities $(\mathrm{O})$ & $\mathrm{W}_{\mathrm{O} 1}=0.1072$ & 4.55 & 0.2079 & \\
& $\mathrm{~W}_{\mathrm{O} 2}=0.1652$ & 4.30 & 0.3027 & \\
& $\mathrm{~W}_{\mathrm{O} 3}=0.4446$ & 3.95 & 0.7485 & \\
& $\mathrm{~W}_{\mathrm{O} 4}=0.2832$ & 4.15 & 0.5009 & \\
\hline \multirow{5}{*}{ Threats $(\mathrm{T})$} & $\mathrm{W}_{\mathrm{T} 1}=0.1559$ & -2.80 & -0.0383 & \\
& $\mathrm{~W}_{\mathrm{T} 2}=0.1195$ & -3.25 & -0.0341 & $\sum_{\mathrm{Ti}}=-0.3016$ \\
& $\mathrm{~W}_{\mathrm{T} 3}=0.4391$ & -3.60 & -0.1389 & \\
\hline & $\mathrm{W}_{\mathrm{T} 4}=0.2856$ & -3.60 & -0.0903 & \\
\hline
\end{tabular}

The strategic quadrilateral is divided into four triangles with different areas by the coordinate axis, and the triangles are located in different quadrants. By calculating their areas, the direction of the tourism cooperation development strategy between Azerbaijan and China under the BRI is determined (Figure 2). 


\subsubsection{Strategic Vector $(\theta, \rho)$}

The center of gravity coordinate: $p(\mathrm{x}, \mathrm{y})=(0.06,0.35)$.

Strategic azimuth: $\theta=\arctan \frac{y}{x} \approx 5.83 \approx 80.27^{\circ}\left(\frac{\pi}{4} \leq \theta \leq \frac{\pi}{2}\right)$.

The strategic strength coefficient is: $\rho=\frac{S \times O}{S \times O+W \times T}=0.88>0.5$.

As can be seen from Figure 3 , the fixed-point coordinates are $(\theta, \rho)=\left(80.27^{\circ}, 0.88\right)$. Therefore, a map of strategic types and intensity of tourism cooperation development between Azerbaijan and China under the BRI was constructed. In Figure 3, the ordinal pair $\mathrm{B}(0.88,5.83)$ represents a strategic vector with an azimuth angle of $5.83\left(80.27^{\circ}\right)$ and a modulus of 0.88 .

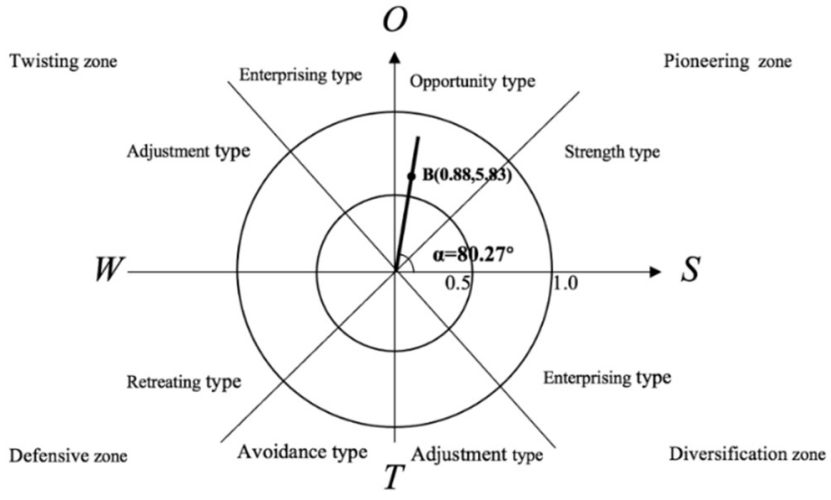

Figure 3. Strategic type and strategic intensity diagram.

\subsection{Results}

Using the SWOT-AHP method, it is concluded that the strategic azimuth $\theta$ falls between $\mathrm{S}$ and $\mathrm{O}$, and that the tourism cooperation development strategy of Azerbaijan and China exhibits internal advantages and external opportunities. This means adopting a pioneering strategy would be appropriate. At the same time, due to the strategic intensity $\rho>0.5$, the adopted strategy implementation intensity is relatively large. In other words, a pioneering development strategy that combines internal advantages with external opportunities would represent the ideal choice.

\section{Discussion}

The results of this paper show that the opportunities and strengths related to the tourism industry are more important than the weaknesses and threats. Azerbaijan and China's tourism cooperation should take the form of a pioneering development strategy (SO development strategy) that combines internal strengths with external opportunities, as explained below.

At first, in the strength group, Azerbaijan and China both have rich tourism resources and great potential for cooperation, as (S4) is the highest rated factor. The broad-based cultural and natural heritages of Azerbaijan and China have created their own unique natural landscapes, and the two countries have shared the heritage of the ancient Silk Road culture for over two millennia. With the gradual implementation of the BRI and the steady development of international relations between Azerbaijan and China, the overall environment for tourism cooperation between Azerbaijan and China appears set for continual improvement. Therefore, it is necessary to carry out sustainable tourism activities based on the characteristics and cultural characteristics of the tourism resources of the two countries.

Secondly, in the opportunity group, Azerbaijan's tourism infrastructure services lag behind those of China, as (W3) is the highest rated factor. In 2018, the Ministry of Culture and Tourism of China was established to expand the global influence of Chinese culture through tourism activities. The strong support provided by the Chinese government has promoted the sustainable development of Belt and Road tourism based on the concept of cultural and tourism integration. Therefore, Azerbaijan and China need to capitalize 
on this highly prescient and timely opportunity to promote the sustainable development of the cultural and tourism integration model of the two countries by taking appropriate action in the very near future.

Thirdly, in the weaknesses group, China attaches high importance to the cultural and tourism integration model of the tourism industry, as (O3) is the highest rated factor. The main reasons supporting this are the shortage of special tourism funds and the lack of experience in tourism planning. Therefore, on the one hand, Azerbaijan should learn from the experiences of developed countries in tourism market construction, and on the other should introduce foreign tourism investment and actively inject funds, technologies, and talent from other countries.

Fourthly, in the threat group, there are differences in cultural cognition between Azerbaijan and China, as (T3) is the highest rated factor. Culture is the main area of competitiveness of the tourism industry, and directly affects the development of the country's tourism market. The cultural differences between Azerbaijan and China have affected the tourism cooperation between the two countries. If the two countries can better explain each other's culture from multiple angles, then tourism cooperation between the two countries will likely follow a new route.

At final, the lower-rated factors in weakness and threat groups also cannot be ignored. On the one hand, tourism cooperation between Azerbaijan and China faces fierce competition from the tourism markets of other countries and regions. On the other hand, the cooperation between Azerbaijan and China is mainly in trade tourism and sightseeing tourism, and the forms of tourism products are currently insufficient or too simple. Therefore, Azerbaijan and China should increase the development of tourism products based on religious culture, historical culture, and gastronomic culture so as to enhance the tourist attractions of Azerbaijan and promote sustainable tourism cooperation between the two countries.

\section{Implications and Recommendations}

In order to better develop tourism cooperation between Azerbaijan and China in BRI, the paper puts forward the following four suggestions:

1. Seize the opportunities presented by the BRI and implement an innovative strategy comprising the cooperation mechanism.

Fully capitalize on the advantages and opportunities represented by the One Belt One Road policy, and gradually strengthen cooperation with administrative service agencies and travel agencies in major tourist sources. Azerbaijan and China need to plan and target tourism cooperation and establish a large-capacity tourism resource information sharing platform so as to realize resource sharing, information exchange, mutual promotion, and visitor source exchange, and promote the integration of regional tourism. At the same time, Azerbaijan should strengthen coordination between the government and industry, and build an interactive cooperation mechanism featuring government guidance, enterprise leadership, and social assistance.

2. Emphasize the principles of mutual benefits and common development.

As for the tourism market development cooperation between the two countries, on the basis of adhering to the principle of mutual benefit and common development, the two sides should actively promote cooperation projects that meet the common interests of both sides. Azerbaijan and China should focus on innovating tourism models and strengthen cooperation in the field of tourism policies. Provision of preferential policies and guarantees for tourism enterprises and travel agencies on both sides should be encouraged. Azerbaijan and China can make use of tourism media to interpret tourism policies from multiple perspectives, all aspects, and multiple levels. This will enable tourism-related companies of the two countries to obtain tourism policy information in a timely manner, fully grasp the related implications, outcomes, or consequences, and apply such to their tourism practices. 
3. Shaping distinctive cultural brands and expanding the tourism industry chain.

Support the research and development of tourism products and design tourism products with cultural elements and symbols of the ancient Silk Road so as to realize the 'aftertaste effect' of cultural products. Improve the relevance of the tourism industry and broaden the development space for the integration of the tourism industry. Integrate tourism and the catering industry, fully capitalize on Azerbaijan's traditional folk snacks, and develop dishes that meet the common tastes of both Azerbaijan and China. Create a distinctive catering brand and improve the quality of catering. At the same time, the catering industry should be combined with the hotel industry to create a distinctive and competitive accommodation brand.

\section{Strengthen interregional multilateral cooperation in tourism}

Tourism investment from China alone is far from sufficient to promote the development of tourism in Azerbaijan. Azerbaijan's hotel construction can introduce foreign tourism investment, and the development of tourism products can be informed by China's legacy for innovation. When constructing cultural tourism cooperation zones based on the five Central Asian countries and the three Caucasus countries, actively inject important development elements such as capital, technology, talent, and management skills from China.

\section{Conclusions}

At present, the number of tourists in the Belt and Road area accounts for more than $70 \%$ of the world's total international tourism [70]. The Belt and Road region, which covers more than $65 \%$ of the world's population, has become the largest regional tourism market. However, the academic community has yet to take this up as a research topic. In order to fill this gap, based on the Delphi method, this paper uses the AHP-SWOT method to identify a pioneering development strategy that combines the internal strengths and external opportunities within the tourism cooperation strategy between Azerbaijan and China under the BRI. The results of this paper show that Azerbaijan and China's tourism cooperation strategy should adopt an SO development approach that combines internal strengths with external opportunities.

Therefore, the specific tourism cooperation development strategy between Azerbaijan and China under the BRI proposed under this study is as follows: (1) seize the opportunities represented by the BRI and implement an innovation strategy involving the cooperation mechanism; (2) emphasize the principle of mutual benefits and common development; (3) shape distinctive cultural brands and expand the tourism industry chain; and (4) strengthen interregional multilateral cooperation in tourism.

It should be noted that this paper uses SWOT-AHP to analyze the tourism cooperation strategy between Azerbaijan and China under the BRI, which not only provides a forwardlooking strategy for the development of sustainable tourism cooperation between the two countries, but also contributes to the sustainable development of tourism cooperation between other countries under the BRI through the provision of related knowledge.

The initial indicators provided by SWOT in this article were selected by the Delphi method and were modified according to expert suggestions. Therefore, to a certain extent, the choice of indicators in this study was based on the subjective judgment of experts, which introduces certain limitations and may lead to underrepresentation. Furthermore, this study randomly selected 700 tourists from China overnighting in Azerbaijan as questionnaire survey subjects, which also imposed certain limitations in terms of the results of the present paper. Therefore, it is recommended that researchers use more diverse methods to select indicators in the future. Furthermore, future research could involve a higher number of experts in differing fields to expand the scope of analysis and provide higher quality comparison based on their opinions to provide more reliable data. 
Author Contributions: Y.L. and S.S. wrote the main manuscript text and prepared figures. All authors reviewed the manuscript. All authors have read and agreed to the published version of the manuscript.

Funding: This research was funded by Nagasaki University "Doctoral Program for World-leading Innovative and Smart Education" for Global Health, KENKYU SHIDO KEIHI ("the Research Grant").

Institutional Review Board Statement: Not applicable.

Informed Consent Statement: Written informed consent has been acquired from the participants of this research to publish this paper.

Data Availability Statement: All sources have been provided in the paper.

Acknowledgments: The authors would like to thank the Nagasaki University WISE Programme for the financial support.

Conflicts of Interest: The authors declare no conflict of interest.

\section{References}

1. Shah, A. Building a sustainable 'Belt and Road'. Horiz. J. Int. Relat. Sustain. Dev. 2016, 7, 212-223.

2. Swain, M.D. China's views and comments on the "Belt and Road" initiative. China Leadersh. Monit. 2015, 47, 3.

3. Aoyama, R. "One belt, one road": China's new global strategy. J. Contemp. East Asia Stud. 2016, 5, 3-22. [CrossRef]

4. Kuchumov, A.; Testina, Y. The Impact of Participation in the Belt and Road Initiative on the Tourist Flows. In New Silk Road: Business Cooperation and Prospective of Economic Development (NSRBCPED 2019); Atlantis Press: Dordrecht, The Netherlands, 2020; pp. 51-57.

5. Winter, T. One belt, one road, one heritage: Cultural diplomacy and the Silk Road. Diplomat 2016, 29, 1-5.

6. Sarker, M.N.I.; Hossin, M.A.; Yin, X.; Sarkar, M.K. One belt one road initiative of China: Implication for future of global development. Mod. Econ. 2018, 9, 623-638. [CrossRef]

7. Georgiev, G.T. The Chinese "One Belt, One Road" initiative-new opportunities for the European Union and its neighbours in the Black Sea region. KSI Trans. Knowl. Soc. 2015, 8, 33-40.

8. Punyaratabandhu, P.; Swaspitchayaskun, J. The political economy of China-Thailand development under the one belt one road initiative: Challenges and opportunities. Chin. Econ. 2018, 51, 333-341. [CrossRef]

9. Alizadeh, A.A.; ogly Guliyev, I.S.; Kadirov, F.A.; Eppelbaum, L.V. Geosciences of Azerbaijan; Springer: Heidelberg, Germany, 2016; Volume 1, p. 237.

10. Mamedov, Z.F. One belt and one road: Participation and role of Azerbaijan in the implementation of the megaproject. In Proceedings of the 55th International Scientific Conference on Economic and Social Development, Baku, Azerbaijan, 18-19 June 2020; Volume 25, pp. 406-412.

11. Gabusi, G. "Crossing the river by feeling the gold": The Asian Infrastructure Investment Bank and the financial support to the Belt and Road Initiative. China World Econ. 2017, 25, 23-45. [CrossRef]

12. Hajizade, E.M. Great Silk Road and the" Baku-Tbilisi-Kars" Project. Black Sea Sci. J. Acad. Res. 2015, 22, 59-68.

13. Chaziza, M. China's New Silk Road Strategy and the Turkish Middle Corridor Vision. Asian J. Middle East. Islamic Stud. 2021, 15, 34-50. [CrossRef]

14. Zeybek, H. What Role for Railways in the Eurasian Supply Chains? In Railway Transportation in South Asia; Springer: Cham, Switzerland, 2021; pp. 269-292.

15. Samedova, E.; Abasova, Y. Strategic governance of tourism development in azerbaijan: Practical aspects and a mechanism for improvement. Econ. Soc. Dev. Book Proc. 2020, 3, 521-532.

16. Tim, W. Heritage diplomacy along the One Belt One Road. Newsletter 2016, 74, 8-10.

17. Sharon, G.M.K.; Andrei, O. Regional integration in Central Asia: Rediscovering the Silk Road. Tour. Manag. Perspect. 2017, 22, 64-66.

18. Feng, T.T.; Kang, Q.; Pan, B.B.; Yang, Y.S. Synergies of sustainable development goals between China and countries along the Belt and Road initiative. Curr. Opin. Environ. Sustain. 2019, 39, 167-186. [CrossRef]

19. Menhas, R.; Mahmood, S.; Tanchangya, P.; Safdar, M.N.; Hussain, S. Sustainable development under belt and road initiative: A case study of China-Pakistan economic corridor's socio-economic impact on Pakistan. Sustainability 2019, 11, 6143. [CrossRef]

20. Dong, S.; Li, Z.; Li, Y.; Shi, G.; Yu, H.; Wang, J.; Li, J.; Mao, Q.; Huang, Y. Resources, environment and economic patterns and sustainable development modes of the Silk Road Economic Belt. J. Resour. Ecol. 2015, 6, 65-72.

21. Wang, X.; Wong, Y.D.; Li, K.X.; Yuen, K.F. Transport research under Belt and Road Initiative: Current trends and future research agenda. Transp. A Transp. Sci. 2021, 17, 357-379. [CrossRef]

22. Valentin, E.K. Swot Analysis from a Resource-Based View. J. Mark. Theory Pract. 2001, 9, 54-69. [CrossRef]

23. Han, X.; Webber, M. From Chinese dam building in Africa to the Belt and Road Initiative: Assembling infrastructure projects and their linkages. Political Geogr. 2020, 77, 102102. [CrossRef]

24. Gurel, M.; Tat, M. SWOT analysis: A theoretical review. J. Int. Soc. Res. 2017, 10, 994-1006. [CrossRef] 
25. David, W.; Sheila, W. What's swot in strategic analysis? Strateg. Chang. 1998, 7, 101-109.

26. Benzaghta, M.A.; Elwalda, A.; Mousa, M.M.; Erkan, I.; Rahman, M. SWOT analysis applications: An integrative literature review. J. Glob. Bus. Insights 2021, 6, 54-72. [CrossRef]

27. Vlados, C. On a correlative and evolutionary SWOT analysis. J. Strategy Manag. 2019, 12, 347-363. [CrossRef]

28. Hay, G.J.; Castilla, G. OBJECT-based image analysis: Strengths, weaknesses, opportunities and threats (SWOT). The International Archives of the Photogrammetry. In Proceedings of the Remote Sensing and Spatial Information Sciences, Atlanta, GA, USA, 12-16 July 2006.

29. Chen, J.; Cui, F.; Balezentis, T.; Streimikiene, D.; Jin, H. What drives international tourism development in the Belt and Road Initiative? J. Destin. Mark. Manag. 2021, 19, 100544. [CrossRef]

30. Khan, A.; Chenggang, Y.; Hussain, J.; Bano, S.; Nawaz, A. Natural resources, tourism development, and energy-growth-CO 2 emission nexus: A simultaneity modeling analysis of BRI countries. Resour. Policy 2020, 68, 101751. [CrossRef]

31. Bai, J.; Chen, Y.; Long, Y. The structural equivalence of tourism cooperative network in the Belt and Road Initiative Area. Environ. Res. 2021, 197, 111043. [CrossRef] [PubMed]

32. Mukeshimana, M.C.; Zhao, Z.Y.; Ahmad, M.; Irfan, M. Analysis on barriers to biogas dissemination in Rwanda: AHP approach. Renew. Energy 2021, 163, 1127-1137. [CrossRef]

33. Sałabun, W.; Wątróbski, J.; Shekhovtsov, A. Are MCDA Methods Benchmarkable? A Comparative Study of TOPSIS, VIKOR, COPRAS, and PROMETHEE II Methods. Symmetry 2020, 12, 1549. [CrossRef]

34. Hu, X.; Ma, C.; Huang, P.; Guo, X. Ecological vulnerability assessment based on AHP-PSR method and analysis of its single parameter sensitivity and spatial autocorrelation for ecological protection-A case of Weifang City, China. Ecol. Indic. 2021, 125, 107464. [CrossRef]

35. Ying, X.; Zeng, G.M.; Chen, G.Q.; Tang, L.; Wang, K.L.; Huang, D.Y. Combining AHP with GIS in synthetic evaluation of eco-environment quality-A case study of Hunan Province, China. Ecol. Model. 2007, 209, 97-109. [CrossRef]

36. $\mathrm{Xu}, \mathrm{S}$.; $\mathrm{Xu}, \mathrm{D}$;; Liu, L. Construction of regional informatization ecological environment based on the entropy weight modified AHP hierarchy model. Sustain. Comput. Inform. Syst. 2019, 22, 26-31. [CrossRef]

37. Saaty, T.L. Decision-making with the AHP: Why is the principal eigenvector necessary. Eur. J. Oper. Res. 2003, 145, 85-91. [CrossRef]

38. Saaty, T.L. Decision making-The analytic hierarchy and network processes (AHP/ANP). J. Syst. Sci. Syst. Eng. 2004, 13, 1-35. [CrossRef]

39. Kwong, C.K.; Bai, H. Determining the importance weights for the customer requirements in QFD using a fuzzy AHP with an extent analysis approach. Iie Trans. 2003, 35, 619-626. [CrossRef]

40. Kwong, C.K.; Bai, H. A fuzzy AHP approach to the determination of importance weights of customer requirements in quality function deployment. J. Intell. Manuf. 2002, 13, 367-377. [CrossRef]

41. Catron, J.; Stainback, G.A.; Dwivedi, P.; Lhotka, J.M. Bioenergy development in Kentucky: A SWOT-ANP analysis. For. Policy Econ. 2013, 28, 38-43. [CrossRef]

42. Ghorbani, A.; Raufirad, V.; Rafiaani, P.; Azadi, H. Ecotourism sustainable development strategies using SWOT and QSPM model: A case study of Kaji Namakzar Wetland, South Khorasan Province, Iran. Tour. Manag. Perspect. 2015, 16, 290-297. [CrossRef]

43. Arsić, S.; Nikolić, D.; Živković, Ž. Hybrid SWOT-ANP-FANP model for prioritization strategies of sustainable development of ecotourism in National Park Djerdap, Serbia. For. Policy Econ. 2017, 80, 11-26. [CrossRef]

44. Marttunen, M.; Lienert, J.; Belton, V. Structuring problems for Multi-Criteria Decision Analysis in practice: A literature review of method combinations. Eur. J. Oper. Res. 2017, 263, 1-17. [CrossRef]

45. Ho, W. Integrated analytic hierarchy process and its applications-A literature review. Eur. J. Oper. Res. 2008, 186, 211-228. [CrossRef]

46. Szulecka, J.; Zalazar, E.M. Forest plantations in Paraguay: Historical developments and a critical diagnosis in a SWOT-AHP framework. Land Use Policy 2017, 60, 384-394. [CrossRef]

47. Haque, H.E.; Dhakal, S.; Mostafa, S.M.G. An assessment of opportunities and challenges for cross-border electricity trade for Bangladesh using SWOT-AHP approach. Energy Policy 2020, 137, 111118. [CrossRef]

48. Ali, E.B.; Agyekum, E.B.; Adadi, P. Agriculture for Sustainable Development: A SWOT-AHP Assessment of Ghana's Planting for Food and Jobs Initiative. Sustainability 2021, 13, 628. [CrossRef]

49. Zorlu, K.; Yilmaz, A. Determination of Strategies of Ecotourism in Protected Areas with SWOT-AHP Method: The Case of Aksaray-Ihlara Special Environmental Protection Zone (SEPZ). Coğrafya Derg. 2020, 40, 247-257.

50. Bianco, S.; Marcianò, C. Using an Hybrid AHP-SWOT Method to Build Participatory Ecotourism Development Strategies: The Case Study of the Cupe Valley Natural Reserve in Southern Italy. In International Symposium on New Metropolitan Perspectives, Springer: Cham, Switzerland, 2018; pp. 327-336.

51. Barrios, M.; Guilera, G.; Nuño, L.; Gómez-Benito, J. Consensus in the delphi method: What makes a decision change? Technol. Forecast. Soc. Chang. 2021, 163, 120484. [CrossRef]

52. Joshi, A.; Kale, S.; Chandel, S.; Pal, D.K. Likert scale: Explored and explained. Br. J. Appl. Sci. Technol. 2015, 7, 396. [CrossRef]

53. Ghazinoory, S.; Abdi, M.; Azadegan-Mehr, M. Swot Methodology: A State-of-the-Art Review for the Past, a Framework for the Future. J. Bus. Econ. Manag. 2011, 12, 24-48. [CrossRef] 
54. Houben, G.; Lenie, K.; Vanhoof, K. A knowledge-based SWOT-analysis system as an instrument for strategic planning in small and medium sized enterprises. Decis. Support Syst. 1999, 26, 125-135. [CrossRef]

55. Reihanian, A.; Mahmood, N.Z.B.; Kahrom, E.; Hin, T.W. Sustainable tourism development strategy by SWOT analysis: Boujagh National Park. Iran. Tour. Manag. Perspect. 2012, 4, 223-228. [CrossRef]

56. Schmoldt, D.; Kangas, J.; Mendoza, G.A.; Pesonen, M. (Eds.) The Analytic Hierarchy Process in Natural Resource and Environmental Decision Making; Springer Science \& Business Media: Berlin/Heidelberg, Germany, 2013; Volume 3.

57. Zhou, M.; Jin, T.; Li, J.; Zhang, S.; Hu, M. Analysis on the Accuracy of Marine Gravity Inversion from the Wide-swath Altimeter Mission. In Proceedings of the EGU General Assembly Conference, Vienna, Austria, 4-8 May 2020; p. 12239.

58. Abdel-Basset, M.; Mohamed, M.; Smarandache, F. An Extension of Neutrosophic AHP-SWOT Analysis for Strategic Planning and Decision-Making. Symmetry 2018, 10, 116. [CrossRef]

59. Chang, H.-H.; Huang, W.-C. Application of a quantification SWOT analytical method. Math. Comput. Model. 2006, 43, 158-169. [CrossRef]

60. Riyadi, A.; Bakar, M.A.A.; Hidayat, C. Opportunities and Challenges of Globalisation for ASEAN Destinations through the One Belt One Road Initiative. In Marketing Tourist Destinations in Emerging Economies; Palgrave Macmillan: Cham, Switzerland, 2022; pp. 259-273.

61. Guo, X. A Study on the International Tourism of Jiangxi Province under the Guidance of One Belt, One Road Strategy. Econ. Soc. Changes Facts Trends Forecast 2016, 3, 221-230. [CrossRef]

62. Kashyap, U.; Bothra, N. Sino-US trade and trade war. Manag. Econ. Res. J. 2019, 5, 10173. [CrossRef]

63. Myeong, S.; Jung, Y.; Lee, E. A Study on Determinant Factors in Smart City Development: An Analytic Hierarchy Process Analysis. Sustainability 2018, 10, 2606. [CrossRef]

64. Munda, G. Multiple Criteria Decision Analysis and Sustainable Development. In State of the Art Surveys, 2nd ed.; Greco, S.M., Ehrgott, J.M., Figueira, R., Price, C.C., Eds.; Springer: New York, NY, USA, 2016; Volume 233, pp. $1235-1267$.

65. Kim, Y.-J.; Park, J. A Sustainable Development Strategy for the Uzbekistan Textile Industry: The Results of a SWOT-AHP Analysis. Sustainability 2019, 11, 4613. [CrossRef]

66. Bakioglu, G.; Atahan, A.O. AHP integrated TOPSIS and VIKOR methods with Pythagorean fuzzy sets to prioritize risks in self-driving vehicles. Appl. Soft Comput. 2021, 99, 106948. [CrossRef]

67. Zyoud, S.H.; Fuchs-Hanusch, D. A bibliometric-based survey on AHP and TOPSIS techniques. Expert Syst. Appl. 2017, 78, 158-181. [CrossRef]

68. Liberatore, M.J.; Nydick, R.L. The analytic hierarchy process in medical and health care decision making: A literature review. Eur. J. Oper. Res. 2008, 189, 194-207. [CrossRef]

69. Wang, Y.M.; Luo, Y. On rank reversal in decision analysis. Math. Comput. Model. 2009, 49, 1221-1229. [CrossRef]

70. Zhifei, L.I.; Chenchen, Z. International Tourism Cooperation Based on "the Belt and Road": Strategy and Path. Confront. Coop. 1000 Years Pol.-Ger.-Russ. Relat. 2020, 6, 25-31. [CrossRef] 